\title{
TRANSPORT OF AMINO ACIDS INTO THE ESTROGEN-PRIMED UTERUS
}

\author{
IV. EFFECTS OF SULFHYDRYL AGENTS ON THE UPTAKE IN VITRO* \\ HSIEN-WEN FENG ${ }^{\star *}$ and THOMAS R. RIGGS ${ }^{\star \star *}$ \\ Department of Biological Chemistry, The University of Michigan, Ann Arbor, Mich. 48 I04 (U.S.A.)
}

(Received March 26th, 1973)

\section{SUMMARY}

1. Sulfhydryl agents have been found to stimulate uptakes of some amino acids by the immature rat uterus in vitro, and to inhibit the uptakes of others. Those whose uptakes were stimulated can enter the cells well by the $L$ transport system for amino acids, while those inhibited use the $A$ system. Uptake of 1-aminocyclopentanecarboxylic acid (cycloleucine), which probably involves both systems, could be stimulated or inhibited, depending on the conditions.

2. The results suggest that the uterus contains at least two kinds of groups that react with $\mathrm{SH}$ agents and are involved in amino acid transport. $\mathrm{N}$-Ethylmaleimide combines relatively rapidly with one type, apparently involving the $\mathrm{L}$ system, to produce stimulation of amino acid transport; but it combines more slowly with the other, the A system, to inhibit transport.

3. The stimulation of amino acid uptake by estradiol, which probably involves the A system, can be inhibited by $N$-ethylmaleimide. This inhibition, however, is apparently not due to an action of $\mathrm{N}$-ethylmaleimide to prevent a possible binding of the hormone to necessary uterine sites.

4. The stimulation of amino acid uptake by $N$-ethylmaleimide appears to be independent of the stimulation by estradiol.

\section{INTRODUCTION}

Estradiol-17 $\beta$ has been shown to increase the uptake of a number of amino acids into the immature rat uterus in vitro if it is injected into the animal 0.5 to $\mathrm{I} \mathrm{h}$ before the tissue is removed ${ }^{2.3}$. On the other hand, sulfhydryl agents can in some cases stimulate transport of biological substances across membranes ${ }^{4,5}$, although

Abbreviation: PCMS, p-chloromercuriphenylsulfonate.

* Part of this work has appeared earlier in abstract ${ }^{1}$.

${ }^{\star *}$ This work was taken from the dissertation of $\mathrm{H}$. W. Feng that was submitted to the Horace H. Rackham School of Graduate Studies, The University of Michigan, in partial fulfillment of the requirements for the degree Doctor of Philosophy.

Present address: Department of Biochemistry, National Defense Medical Center, Box 7432, Taipei, Taiwan, Republic of China.

*** To whom requests for reprints should be addressed. 
more frequently they inhibit it ${ }^{6}$. Recently, several pieces of evidence have been presented that suggest that uterine sulfhydryl groups may be involved in the physiological action of the estrogens. For example, Jensen and co-workers ${ }^{7}$ have presented evidence that sulfhydryl groups may be necessary in the receptor sites for estradiol in the uterus; and Ukolova and Kvakina ${ }^{8}$ have reported that thiols and thiol-reacting compounds can mimic certain of the actions of the estrogens. Furthermore, Batt and Schachter ${ }^{9}$ found a protective effect of estrogen against the action of $N$-ethylmaleimide on sulfhydryl groups of the galactoside transport system.

In our earlier work ${ }^{3}$, we found that iodoacetate, a sulfhydryl agent, could inhibit the uptake of $\alpha$-aminoisobutyric acid by the rat uterus in vitro. This fact, together with the evidence that $\mathrm{SH}$ groups may be involved in estrogen action, suggested to us that estradiol may alter amino acid transport through reaction with thiol groups of the uterus. Our further studies have shown that sulfhydryl agents can not only inhibit uptake of some amino acids by the uterus, but that they can stimulate uptake of others. The inhibition but not the stimulation appears related to the action of estradiol on transport. This paper presents these results and other work describing the two different effects of sulfhydryl agents on amino acid transport in the uterus.

\section{MATERIALS AND METHODS}

Procedures and techniques were generally similar to those used in our earlier work $^{3}$. Amino acid uptake was measured isotopically in vitro in uteri removed from immature Sprague-Dawley female rats. The incubation medium was Krebs-Ringer bicarbonate buffer solution or modifications of it, gassed with $\mathrm{O}_{2}-\mathrm{CO}_{2}(95: 5, \mathrm{v} / \mathrm{v})$. In those cases in which the uterus was preincubated with various agents, the following procedure was used: after the preincubation, the tissue was rinsed by placing it sequentially into 2 beakers, each containing $1 \mathrm{ml}$ of ice-cold Krebs-Ringer bicarbonate buffer per uterus. It was then briefly blotted and put at once in the proper medium for further incubation. Preparation of the samples for analysis was similar to that reported previously ${ }^{3}$.

Amino acid was determined by radioactive counting, using a Unilux or Packard liquid scintillation counter.

In the estrogen experiments, rats were injected subcutaneously with estradiol$17 \beta$ dissolved in $25 \%$ ethanol in $0.85 \% \mathrm{NaCl}$ solution. Control animals received the solvent alone.

Amino acid uptake is usually expressed as distribution ratio, which is the ratio of amino acid level in the uterine cellular water to that in the extracellular water. The amino acid level in the uterine cells was calculated on the basis of cell water. High levels of $N$-ethylmaleimide, or extended incubation with it, were found to alter total tissue water and/or extracellular (sucrose) space (see Table 1). These changes were taken into account in calculating cellular amino acid levels.

\section{RESULTS}

Effect of various sulfhydryl agents on uptake of 1-aminocyclopentanecarboxylic acid (cycloleucine)

Our earlier results showed that a $5 \mathrm{mM}$ level of iodoacetate would inhibit uptake of $\alpha$-aminoisobutyric acid into the immature rat uterus ${ }^{3}$. When a $0.05 \mathrm{mM}$ 


\section{TABLE I}

THE EFFECT OF $N$-ETHYLMALEIMIDE ON TOTAL TISSUE WATER AND EXTRACELLULAR SPACE OF THE IMMATURE RAT UTERUS

Two to six values were averaged in each case.

\begin{tabular}{|c|c|c|}
\hline Preincubation & Incubation * & $\begin{array}{l}\text { Total } \\
\text { tissue water, } \\
\text { as \% of } \\
\text { wet weight }\end{array}$ \\
\hline $10 \mathrm{~min}, 5 \mathrm{mM} \mathrm{N}$-ethylmaleimide & $30 \mathrm{~min}$ & 86.1 \\
\hline $2 \mathrm{~min}, 5 \mathrm{mM} \mathrm{N}$-ethylmaleimide & $30 \mathrm{~min}$ & 85.1 \\
\hline $10 \mathrm{~min}, 1 \mathrm{mM} N$-ethylmaleimide & $30 \mathrm{~min}$ & 83.1 \\
\hline $20 \mathrm{~min}, 0.3 \mathrm{mM} N$-ethylmaleimide & $2 \mathrm{~h}$ & 82.2 \\
\hline None & $2 \mathrm{~h}, 0.5 \mathrm{mM} \mathrm{N}$-ethylmaleimide & 81.0 \\
\hline None & $2 \mathrm{~h}, 0.2 \mathrm{mM} N$-ethylmaleimide & 83.2 \\
\hline $10 \mathrm{~min}, 1 \mathrm{mM}$ PCMS & $30 \mathrm{~min}$ & 80.7 \\
\hline None & Control ${ }^{\star \star \star}$ & 81.3 \\
\hline
\end{tabular}

* Incubation in normal buffer with indicated additions.

* * Extracellular fluid space was measured as sucrose space and calculated as per cent of total tissue water.

${ }^{* *}$ Values reported in Paper I*.

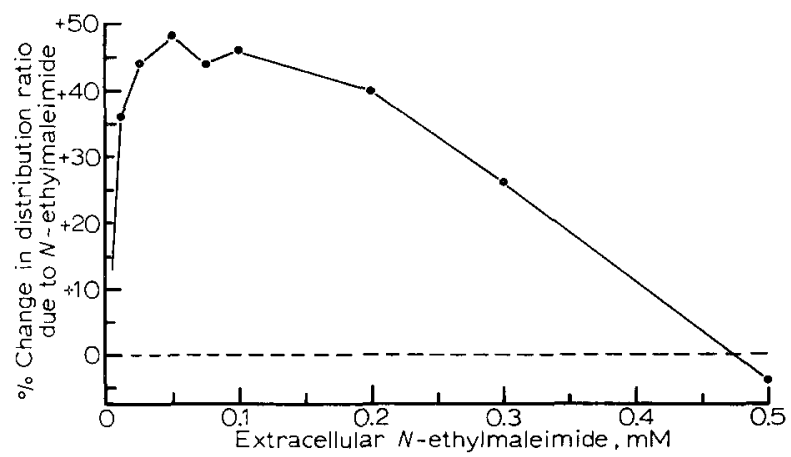

Fig. 1. Effect of $N$-ethylmaleimide at different levels on uptake of cycloleucine in $2 \mathrm{~h}$. Uteri were incubated with $1 \mathrm{mM}$ cycloleucine in buffer containing the indicated level of $N$-ethylmaleimide. 3-8 values averaged for each point. Changes were significantly above zero over the range 0.025 $0.2 \mathrm{mM} N$-ethylmaleimide $(P<0.05$ or $<0.01)$.

level of $\mathrm{N}$-ethylmaleimide was tested for its effect on cycloleucine uptake, however, it was found to produce stimulation (see Fig. 1). A further examination showed that transport of cycloleucine was also increased by the proper condition of treatment with iodoacetate, iodoacetamide, $p$-hydroxymercuribenzoate, or $p$-chloromercuriphenylsulfonate (PCMS) (Table II). Since $N$-ethylmaleimide has a high specificity for SH groups ${ }^{10}$, and gave nearly a $50 \%$ stimulation of cycloleucine uptake, it was used in most of the subsequent studies. 


\section{TABLE II}

\section{EFFECT OF SH AGENTS ON CYCLOLEUCINE UPTAKE}

Part A, uteri were incubated with $1 \mathrm{mM}\left[1-{ }^{14} \mathrm{C}\right]$ cycloleucine for $2 \mathrm{~h}$ with 0 (control) or $0.05 \mathrm{mM}$ SH agent; Part B, uteri were preincubated with a $1 \mathrm{mM}$ level of $\mathrm{SH}$ agent for 10 min (unless otherwise stated), rinsed with buffer, and then incubated with $1 \mathrm{mM}\left[1 .{ }^{14} \mathrm{C}\right]$ cycloleucine for $30 \mathrm{~min}$; Part $\mathrm{C}$, uteri were preincubated for $1 \mathrm{~h}$ with $0-0.3 \mathrm{mM} p$-chloromercuriphenylsulfonate, rinsed with buffer, and then incubated for $2 \mathrm{~h}$ with $1 \mathrm{mM}\left[1-{ }^{14} \mathrm{C}\right]$ cycloleucine. Distribution ratios are averages \pm the standard errors of the means. Three to nine samples per group.

\begin{tabular}{|c|c|c|c|c|c|c|}
\hline \multirow[t]{2}{*}{ SH agent } & \multicolumn{2}{|l|}{ Part $A$} & \multicolumn{2}{|l|}{ Part $B$} & \multicolumn{2}{|l|}{ 3ift $C$} \\
\hline & $\begin{array}{l}\text { Distribution } \\
\text { ratio }\end{array}$ & $\begin{array}{l}\text { \% change } \\
\text { due to } \\
\text { SH agent }\end{array}$ & $\begin{array}{l}\text { Distribution } \\
\text { ratio }\end{array}$ & $\begin{array}{l}\text { \% change } \\
\text { due to } \\
\text { SH agent }\end{array}$ & $\begin{array}{l}\text { Distribution } \\
\text { ratio }\end{array}$ & $\begin{array}{l}\text { on change } \\
\text { cille to } \\
\text { SH agent }\end{array}$ \\
\hline None & $2.08 \pm 0.54$ & & $1.81 \pm 0.06$ & & $3.24 \pm 0.13$ & \\
\hline Iodoacetate & $2.82 \pm 0.26$ & $+36^{\star}$ & $2.19 \pm 0.16$ & $+22^{\star}$ & & \\
\hline $\begin{array}{l}\text { Iodoacetamide } \\
p \text {-Hydroxy- }\end{array}$ & $3.59 \pm 0.25$ & $+73^{\star \star}$ & $2.07 \pm 0.26$ & $+15^{\star}$ & & \\
\hline $\begin{array}{l}\text { mercuribenzoate } \\
\text {-Chloromercuri- } \\
\text { phenylsulfonate }\end{array}$ & $3.34 \pm 0.27$ & $+61^{* *}$ & $1.74 \pm 0.03$ & -3 & & \\
\hline$(\mathrm{PCMS})(0.1 \mathrm{mM})$ & & & $1.78 \pm 0.38$ & -2 & $3.30 \pm 0.53$ & +2 \\
\hline PCMS $(0.2 \mathrm{mM})$ & & & & & $4.06 \pm 0.43$ & $+25^{\star}$ \\
\hline PCMS (0.3 mM) & & & & & $4.05 \pm 0.17$ & $+25^{\star}$ \\
\hline $\operatorname{PCMS}(1 \mathrm{mM})$ & & & $1.01 \pm 0.04$ & $-44^{\star \star}$ & & \\
\hline
\end{tabular}

\section{Effect of $\mathrm{N}$-ethylmaleimide on uptake of different amino acids}

The uptakes of valine, phenylalanine and cycloleucine were all stimulated by $\mathrm{N}$-ethylmaleimide under two different conditions: during a 2-h incubation with amino acid and $\mathrm{SH}$ agent together; or after a 10-min preincubation with $\mathrm{SH}$ agent, followed by incubation with amino acid alone. For cycloleucine, optimal stimulation over $2 \mathrm{~h}$ was given by $0.025-0.1 \mathrm{mM} N$-ethylmaleimide (Fig. 1). At higher $N$-ethylmaleimide levels, the stimulation fell off. For valine and phenylalanine, however, stimulation after $2 \mathrm{~h}$ was given by a $0.5 \mathrm{mM}$ level, but not by $0.05 \mathrm{mM}$ (Table III, part A). When the $N$-ethylmaleimide was preincubated with the uterus, a $1 \mathrm{mM}$ level produced stimulation of all 3 amino acids (Fig. 2; and Table III, part B). On the other hand, $\alpha$-aminoisobutyric acid uptake was inhibited by a $0.5 \mathrm{mM}$ level of $N$-ethylmaleimide in a 2-h incubation (Table III, part A), while a $0.05 \mathrm{mM}$ level was neither stimulatory nor inhibitory. Figs 1 and 2 show that as the $N$-ethylmaleimide level became high enough, even cycloleucine uptake was not stimulated.

\section{Effect of time of exposure of tissue to $N$-ethylmaleimide}

Preliminary results suggested that the stimulation of cycloleucine uptake depended upon both the length of the prior exposure of the tissue to $\mathrm{N}$-ethylmaleimide, and the length of the subsequent incubation period with amino acid. These two factors were therefore examined individually. Two separate types of experiments were carried 
TABLE III

\section{COMPARATIVE EFFECT OF $N$-ETHYLMALEIMIDE ON THE UPTAKES OF DIFFER- ENT AMINO ACIDS}

Part A, uteri were incubated with $1 \mathrm{mM}$ amino acid for $2 \mathrm{~h}$ with the designated level of $N$-ethylmaleimide; Part B, uteri were preincubated for $10 \mathrm{~min}$ with 0 or $1 \mathrm{mM} \mathrm{N}$-ethylmaleimide in buffer, rinsed with buffer and then incubated for $30 \mathrm{~min}$ with $1 \mathrm{mM}$ amino acid. Distribution ratios are averages \pm the standard errors of the means. 3-12 samples per group.

\begin{tabular}{|c|c|c|c|c|c|}
\hline \multirow[t]{2}{*}{ Amino acid } & \multirow{2}{*}{$\begin{array}{l}N-E t h y /- \\
\text { maleimide } \\
(m M)\end{array}$} & \multicolumn{2}{|l|}{ Part $A$} & \multicolumn{2}{|l|}{ Part $B$} \\
\hline & & $\begin{array}{l}\text { Distribution } \\
\text { ratio }\end{array}$ & $\begin{array}{l}\% \text { change } \\
\text { due to } \\
\text { N-ethyl- } \\
\text { maleimide }\end{array}$ & $\begin{array}{l}\text { Distribution } \\
\text { ratio }\end{array}$ & $\begin{array}{l}\% \text { change } \\
\text { due to } \\
N \text {-ethyl- } \\
\text { maleimide }\end{array}$ \\
\hline$\alpha$-Aminoisobutyric acid & 0 & $7.48 \pm 0.47$ & & $2.09 \pm 0.16$ & \\
\hline$\alpha$-Aminoisobutyric acid & 0.05 & $7.13 \pm 0.21$ & -5 & & \\
\hline$\alpha$-Aminoisobutyric acid & 0.50 & $2.56 \pm 0.39$ & $-66^{\star}$ & & \\
\hline$\alpha$-Aminoisobutyric acid & 1.00 & & & $1.85 \pm 0.07$ & -11 \\
\hline L-Proline & 0 & $3.13 \pm 0.27$ & & $2.39 \pm 0.20$ & \\
\hline L-Proline & 0.05 & $3.88 \pm 0.15$ & +23 & & \\
\hline L-Proline & 0.50 & $2.64 \pm 0.25$ & -16 & & \\
\hline L-Proline & 1.00 & & & $2.06 \pm 0.31$ & -14 \\
\hline L-Phenylalanine & 0 & $1.48 \pm 0.17$ & & $1.43 \pm 0.07$ & \\
\hline L-Phenylalanine & 0.05 & $1.36 \pm 0.35$ & -7 & & \\
\hline L-Phenylalanine & 0.50 & $2.31 \pm 0.28$ & $+56^{\star *}$ & & \\
\hline L-Phenylalanine & 1.00 & & & $2.22 \pm 0.09$ & $+55^{\star \star}$ \\
\hline L-Valine & 0 & $1.59 \pm 0.11$ & & $1.82 \pm 0.24$ & \\
\hline L-Valine & 0.05 & $1.88 \pm 0.06$ & +18 & & \\
\hline L-Valine & 0.50 & $2.96 \pm 0.34$ & $+86^{* \star *}$ & & \\
\hline L-Valine & 1.00 & & & $3.82 \pm 0.35$ & $+110^{*}$ \\
\hline
\end{tabular}

${ }^{\star} P<0.01$

${ }^{\star \star} P<0.001$

${ }^{\star \star \star} P<0.05$.

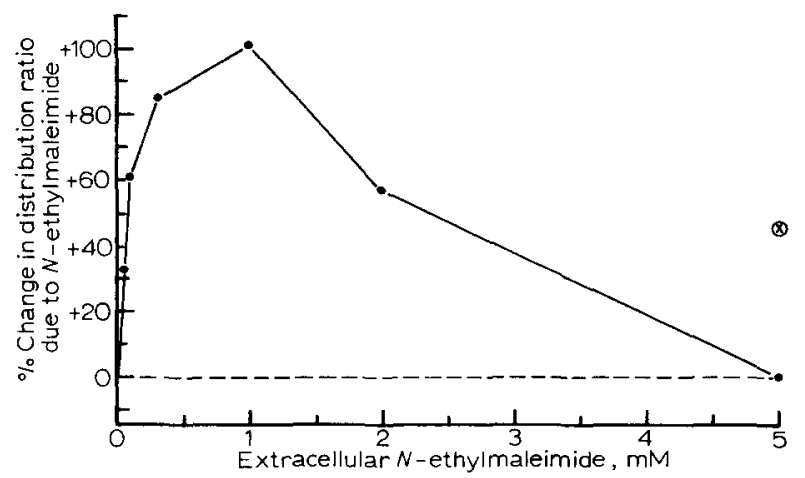

Fig. 2. Effect of different levels of $N$-ethylmaleimide during preincubation on the 30-min uptake of cycloleucine. - uteri preincubated $10 \mathrm{~min}$ with the indicated level of $\mathrm{N}$-ethylmaleimide in buffer, rinsed with buffer and then incubated with $1 \mathrm{mM}$ cycloleucine for $30 \mathrm{~min}$; $\otimes$, same, except the $N$-ethylmaleimide was added during only the final 2 min of the 10 -min preincubation period. $3-12$ values per point. All changes are statistically significant $(P<0.01$ or $<0.05)$. 


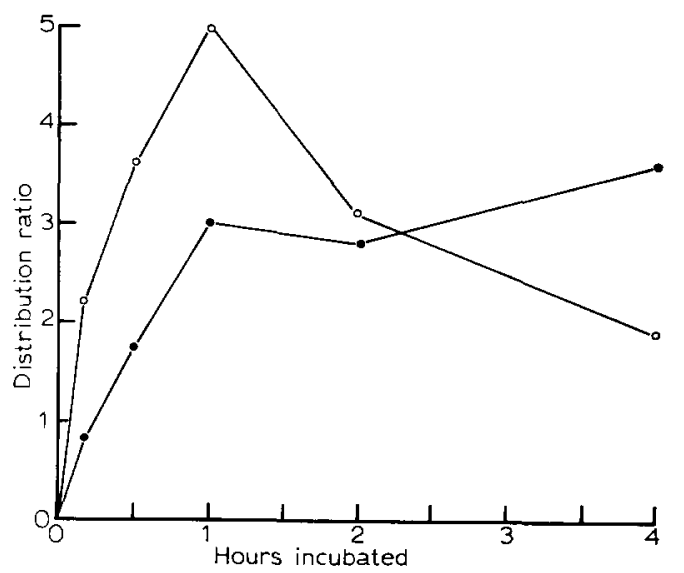

Fig. 3. Effect of incubation time on cycloleucine uptake by uteri pretreated with or without $N$-ethylmaleimide. Uteri were preincubated without $(\bullet)$ or with $(O) 1 \mathrm{mM} \mathrm{N}$-ethylmaleimide in buffer for $10 \mathrm{~min}$, rinsed with buffer and then incubated with $1 \mathrm{mM}$ cycloleucine for the times shown on the abscissa. 3-12 values per point. Changes given by $N$-ethylmaleimide were statistically significant at all times except $2 \mathrm{~h}$.

out in which the preincubation exposure of the uterus to $N$-ethylmaleimide was varied. In the first experiment, a 10 -min exposure to a $5 \mathrm{mM}$ level of $N$-ethylmaleimide had no effect on cycloleucine uptake, whereas a 2-min exposure to the same $N$ ethylmaleimide level produced a $46 \%$ stimulation (points to the far right of Fig. 2 ). In the second experiment, renewal of a $0.05 \mathrm{mM}$ level of $N$-ethylmaleimide two times over a 1 -h preincubation period led to a $17 \%$ inhibition of subsequent amino acid uptake, whereas continued preincubation with the same $0.05 \mathrm{mM} N$-ethylmaleimide solution for $1 \mathrm{~h}$ led to a $44 \%$ stimulation.

Fig. 3 presents a time curve for uptake of cycloleucine into uteri preincubated for $10 \mathrm{~min}$ in the absence $v s$ presence of $1 \mathrm{mM} N$-ethylmaleimide. The tissues pretreated with $\mathrm{N}$-ethylmaleimide showed stimulation of the uptake in incubations with amino acid of $1 \mathrm{~h}$ or less, but not at $2 \mathrm{~h}$. After $4 \mathrm{~h}$, a significant inhibition had occurred.

Attempts to modify the $N$-ethylmaleimide effects by use of agents that might reverse its binding to uterine tissue

Neither Cleland's reagent (dithiothreitol) ( $1 \mathrm{mM})$ nor mercaptoethanol $(2 \mathrm{mM})$ could reverse the effects of $N$-ethylmaleimide on cycloleucine uptake if the uterus was first preincubated with the $N$-ethylmaleimide (Table IV); in fact, the two thiols enhanced the stimulatory action of the $N$-ethylmaleimide (Column 4), as well as uptake in the absence of $N$-ethylmaleimide (Column 2). The thiols did prevent the actions of $N$-ethylmaleimide on the transport, however, if they were added at the same time as the sulfhydryl agent (distribution ratios averaged 2.21 after $30 \mathrm{~min}$ with Cleland's reagent, both in the presence and absence of $1 \mathrm{mM} \mathrm{N}$-ethylmaleimide).

In contrast to the above results, a $1 \mathrm{mM}$ level of PCMS was effective in reducing the stimulation produced by preincubation with $N$-ethylmaleimide, even though the PCMS was present during only the last $10 \mathrm{~min}$ of the incubation with cycloleucine (Table IV, last line). In addition, the inhibition given by preincubation with PCMS was just as great in the presence as in the absence of $\mathrm{N}$-ethylmaleimide in the prein- 


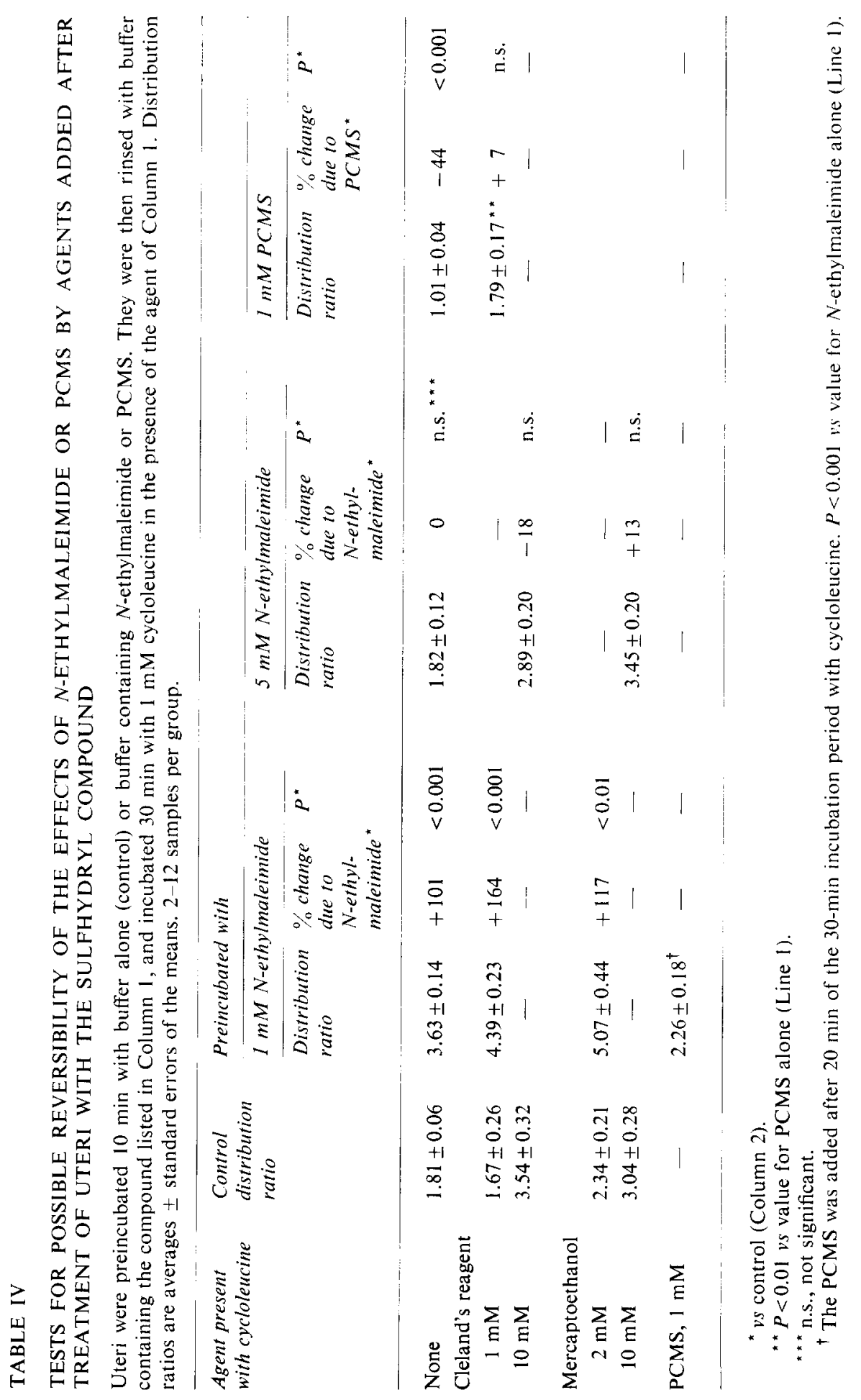


cubation fluid. These results suggest that the PCMS was bound more tightly to the active uterine site than was $N$-ethylmaleimide. Nevertheless, Cleland's reagent could reverse the inhibition produced by preincubation with PCMS; a normal distribution ratio was given when the thiol was added only during the incubation period (Table IV, last 3 columns).

Effect of $N$-ethylmaleimide on cycloleucine uptake by the estradiol-primed uterus

This amino acid was the only one examined whose uptake was found to be increased by both estradiol ${ }^{3}$ and $N$-ethylmaleimide. To test a possible interrelationship between the stimulation of its uptake by these two substances, the effect of the SH agent was measured in uteri primed to different degrees either by varying the dosage of the steroid injected $(0.01-5 \mu \mathrm{g}$ per rat), or by varying the time over which the hormone was allowed to act in vivo $(0-3 \mathrm{~h})$. We reported earlier ${ }^{3}$ that the maximum effect of $1 \mu \mathrm{g}$ estradiol was given after $3 \mathrm{~h}$; the present data show that doses of $0.05-5$ $\mu \mathrm{g}$ estradiol all produced essentially the same, maximum response in this time (Table $\mathrm{V}$, Column 2).

When $N$-ethylmaleimide was added in vitro to the estrogen-primed tissue, its ability to increase the distribution ratio tended to be less as the stimulation by the hormone was increased (compare Columns 2 and 3 of Table $\mathrm{V}$; the trend is suggested especially by the first 6 lines). However, calculation showed that the excess cycloleucine entering the cells due to the presence of $N$-ethylmaleimide was about the same no matter how much stimulat on had been produced by the estradiol (Table V, Column 4).

\section{TABLE V}

\section{EFFECT OF $N$-ETHYLMALEIMIDE ON UPTAKE OF CYCLOLEUCINE BY UTERI FROM ESTRADIOL-PRIMED RATS}

Estradiol was injected subcutaneously according to the conditions of Column I. Uteri were preincubated with 0 or $1 \mathrm{mM} \mathrm{N}$-ethylmaleimide $10 \mathrm{~min}$, rinsed with buffer, and incubated 30 min with $1 \mathrm{mM}$ cycloleucine. 6-21 values per group.

\begin{tabular}{|c|c|c|c|}
\hline \multirow[t]{2}{*}{ Estradiol treatment } & \multicolumn{2}{|c|}{$\%$ change in distribution ratio } & \multirow{2}{*}{$\begin{array}{l}\text { Change in } \\
\text { [cycloleucine }]_{\text {cell }} \\
\text { due to } \\
\text { N-ethylmaleimide* } \\
(m M)\end{array}$} \\
\hline & $\begin{array}{l}\text { Due to } \\
\text { estradio! alone }\end{array}$ & $\begin{array}{l}\text { Due to } \\
\text { N-ethylmaleimide* }\end{array}$ & \\
\hline None & 0 & +101 & +1.8 \\
\hline $0.01 / \mathrm{g}, 3 \mathrm{~h}$ & +24 & +86 & +1.9 \\
\hline $0.02 \mu \mathrm{g}, 3 \mathrm{~h}$ & +44 & +68 & +1.8 \\
\hline $0.1 / 1 \mathrm{~g}, 3 \mathrm{~h}$ & +74 & +64 & +2.0 \\
\hline $0.05 \mu \mathrm{g}, 3 \mathrm{~h}$ & +91 & +55 & +1.9 \\
\hline $1.0, / \mathrm{g}, 3 \mathrm{~h}$ & +107 & +46 & +1.7 \\
\hline $5 \mu \mathrm{g}, 1 / 3 \mathrm{~h}$ & +5 & +120 & +2.3 \\
\hline $5 \mu \mathrm{g}, 1 \mathrm{~h}$ & +35 & +47 & +1.2 \\
\hline $5 \mathrm{~kg}, 2 \mathrm{~h}$ & +50 & +44 & +1.2 \\
\hline $5 \mu \mathrm{g}, 3 \mathrm{~h}$ & +80 & +65 & +2.1 \\
\hline
\end{tabular}

* Change above that produced by estradiol alone. 
On the other hand, the estradiol-primed tissues were more sensitive to $N$-ethylmaleimide inhibition of cycloleucine uptake than were the controls (Fig. 4). Uptake into tissues from hormone-treated rats was significantly inhibited by $N$-ethylmaleimide under conditions that did not affect uptake by control uteri.

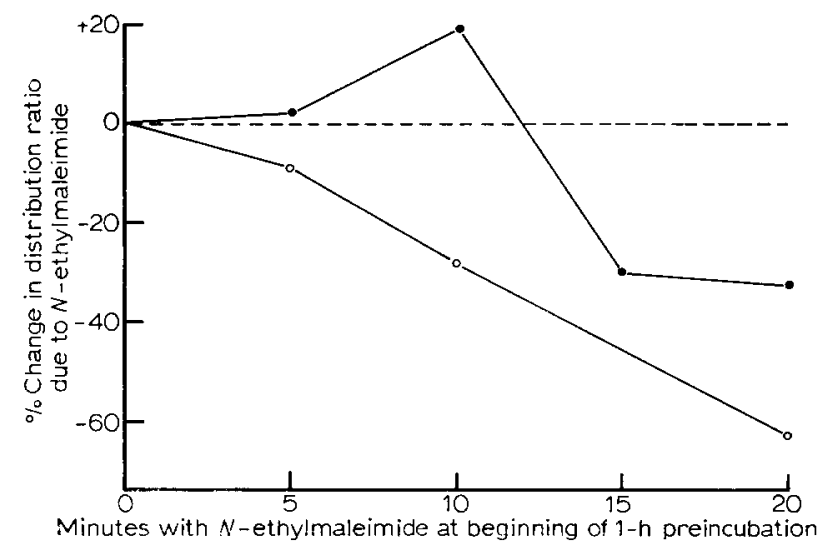

Fig. 4. $N$-Ethylmaleimide inhibition of cycloleucine uptake by uteri from control and estradioltreated rats. Rats were injected subcutaneously with 0 or $5 \mu \mathrm{g}$ estradiol. Their uteri were removed $3 \mathrm{~h}$ later and preincubated with $0.3 \mathrm{mM} N$-ethylmaleimide for the times shown on the abscissa. Tissues were then rinsed with buffer, preincubated in buffer to make the total preincubation time $1 \mathrm{~h}$; rinsed with buffer, and incubated $2 \mathrm{~h}$ with $1 \mathrm{mM}$ cycloleucine. $4-16$ values per point. - control; ostradiol-primed. Decreases are statistically significant in estradiol-primed tissues preincubated with $\mathrm{N}$-ethylmaleimide for 10 and $20 \mathrm{~min}$; other changes were found not to be significantly different from zero.

\section{Relation of the $\mathrm{N}$-ethylmaleimide effect to the buffer $\left[\mathrm{Na}^{+}\right]$}

Replacing the buffer $\mathrm{Na}^{+}$with choline ${ }^{+}$eliminated the stimulation of cycloleucine uptake normally given by preincubation with $N$-ethylmaleimide, and it reduced the effect on L-phenylalanine and L-valine uptake (Table VI). Addition of $0.02 \mathrm{mM}$ ouabain also reduced the stimulation of cycloleucine uptake normally given by 0.05 $\mathrm{mM} \mathrm{N}$-ethylmaleimide, from $49 \%$ to only $15 \%$. The increase was, nevertheless, still significant $(P<0.05)$.

\section{Sensitivity of the preincubated uterus to the action of $N$-ethylmaleimide on uptake}

As reported in the second paper of this series ${ }^{11}$, cycloleucine is among those amino acids whose uptakes can be greatly increased if the uterus is preincubated with normal buffer for several hours before amino acid is added. The sensitivity of uptake to $\mathrm{N}$-ethylmaleimide was therefore measured after a 4 -h preincubation of the tissue (Table VII). Low levels of $N$-ethylmaleimide produced the same absolute increment of increase as found in normal tissues; but the per cent change was less than normal because the control value had been more than doubled. Under the proper conditions of testing, the stimulation was still significant statistically. A $0.5 \mathrm{mM}$ level of $N$-ethylmaleimide for $2 \mathrm{~h}$, in contrast, brought the distribution ratio down to the same value in both the preincubated and control uteri ( 1.92 vs 1.99 ; compare values in Table VII and Fig. 1). The decrease was therefore much greater in the preincubated tissue, whether calculated in absolute terms or as a per cent of normal (Table VII, line 3). 


\section{TABLE VI}

\section{MODIFICATION OF THE $N$-ETHYLMALEIMIDE EFFECTS BY Na ${ }^{+}$-FREE BUFFER}

Uteri were preincubated for $10 \mathrm{~min}$ with the indicated level of $\mathrm{N}$-ethylmaleimide, and then incubated with $1 \mathrm{mM}$ amino acid for $60 \mathrm{~min}$ (cycloleucine) or $30 \mathrm{~min}$ (phenylalanine and valine). A $\mathrm{Na}^{+}$-free buffer solution was made by replacing $\mathrm{Na}^{+}$in all reagents and the incubation media with choline ion. Distribution ratios are averages \pm standard errors of the means. 3-12 samples per group.

\begin{tabular}{|c|c|c|c|c|c|c|c|}
\hline \multirow[t]{2}{*}{ Amino acid } & \multirow{2}{*}{$\begin{array}{l}N \text {-Ethyl- } \\
\text { maleimide } \\
(m M)\end{array}$} & \multicolumn{3}{|l|}{$\mathrm{Na}^{+}$-free } & \multicolumn{3}{|l|}{$143 \mathrm{mM} \mathrm{Na}^{+}$} \\
\hline & & $\begin{array}{l}\text { Distribution } \\
\text { ratio }\end{array}$ & $\begin{array}{l}\% \text { change } \\
\text { due to } \\
N \text {-ethyl- } \\
\text { maleimide }\end{array}$ & $P$ & $\begin{array}{l}\text { Distribution } \\
\text { ratio }\end{array}$ & $\begin{array}{l}\% \text { change } \\
\text { due to } \\
N \text {-ethyl- } \\
\text { maleimide }\end{array}$ & $P$ \\
\hline Cycloleucine & 0 & $1.87 \pm 0.06$ & & & $3.01 \pm 0.22$ & & \\
\hline Cycloleucine & 0.05 & $1.91 \pm 0.13$ & +2 & n.s. * & $4.49 \pm 0.43$ & +49 & $<0.05$ \\
\hline Cycloleucine & 5 & $1.94 \pm 0.18$ & +4 & n.s. & $2.34 \pm 0.32$ & -22 & n.s. \\
\hline L-Phenylalanine & 0 & $1.11 \pm 0.03$ & & & $1.43 \pm 0.07$ & & \\
\hline L-Phenylalanine & 1 & $1.48 \pm 0.10$ & +33 & $<0.05$ & $2.22 \pm 0.09$ & +55 & $<0.001$ \\
\hline L-Valine & 0 & $1.54 \pm 0.04$ & & & $1.82 \pm 0.24$ & & \\
\hline L-Valine & 1 & $1.88 \pm 0.06$ & +22 & $<0.01$ & $3.82 \pm 0.35$ & +110 & $<0.05$ \\
\hline
\end{tabular}

\section{TABLE VII}

\section{MODIFICATION OF THE $N$-ETHYLMALEIMIDE EFFECT BY PREINCUBATION}

Part $\mathrm{A}$, uteri were preincubated $4 \mathrm{~h}$ in normal buffer and then incubated $2 \mathrm{~h}$ with $1 \mathrm{mM}\left[1-{ }^{14} \mathrm{C}\right]-$ cycloleucine in buffer containing the indicated level of $N$-ethylmaleimide; Part B, uteri were preincubated $4 \mathrm{~h}$, treated with 0 or $1 \mathrm{mM} \mathrm{N}$-ethylmaleimide for $10 \mathrm{~min}$, rinsed with buffer and then incubated $30 \mathrm{~min}$ with $1 \mathrm{mM}\left[1-{ }^{14} \mathrm{C}\right] \mathrm{cycloleucine}$. Distribution ratios are averages \pm standard errors of the means. 3-9 samples per group.

\begin{tabular}{|c|c|c|c|c|c|}
\hline \multirow{2}{*}{$\begin{array}{l}N \text {-Ethyl- } \\
\text { maleimide } \\
(m M)\end{array}$} & \multirow{2}{*}{$\begin{array}{l}\text { Distribution } \\
\text { ratio }\end{array}$} & \multicolumn{2}{|c|}{ With preincubation } & \multicolumn{2}{|c|}{ Without preincubation ${ }^{*}$} \\
\hline & & $\begin{array}{l}\text { Increment } \\
\text { due to } \\
N \text {-ethyl- } \\
\text { maleimide }\end{array}$ & $\begin{array}{l}\% \text { change } \\
\text { due to } \\
N \text {-ethyl- } \\
\text { maleimide }\end{array}$ & $\begin{array}{l}\text { Increment } \\
\text { due to } \\
\text { N-ethyl- } \\
\text { maleimide }\end{array}$ & $\begin{array}{l}\% \text { change } \\
\text { due to } \\
\text { N-ethyl- } \\
\text { maleimide }\end{array}$ \\
\hline \multicolumn{6}{|l|}{ Part A } \\
\hline 0 & $4.53 \pm 0.66$ & & & & \\
\hline 0.05 & $5.88 \pm 0.44$ & +1.35 & +30 & +1.00 & $+48^{\star \star \star}$ \\
\hline 0.5 & $1.92 \pm 0.11$ & -2.61 & $-58^{\star \star}$ & -0.09 & -5 \\
\hline \multicolumn{6}{|l|}{ Part B } \\
\hline 0 & $4.10 \pm 0.25$ & & & & \\
\hline 1.0 & $5.30 \pm 0.21$ & +1.20 & $+30^{* *}$ & +1.83 & $+101^{* * *}$ \\
\hline
\end{tabular}


Effects of competitive amino acids on the $N$-ethylmaleimide stimulation of uptakes of cycloleucine and phenylalanine

High levels of phenylalanine or $\alpha$-aminoisobutyric acid nearly eliminated the $N$-ethylmaleimide stimulation of cycloleucine uptake (Table VIII, left). In contrast, when phenylalanine uptake was measured, $\alpha$-aminoisobutyric acid had no significant effect, while valine reduced the $N$-ethylmaleimide stimulation by $58 \%$ (Table VIII, right).

\section{TABLE VIII}

COMPARATIVE EFFECTS OF L-PHENYLALANINE, $\alpha$-AMINOISOBUTYRIC ACID AND L-VALINE AS COMPETITORS OF THE $N$-ETHYLMALEIMIDE STIMULATION OF UPTAKES OF CYCLOLEUCINE AND L-PHENYLALANINE

Uteri were preincubated with 0 or $1 \mathrm{mM} \mathrm{N}$-ethylmaleimide in buffer for $10 \mathrm{~min}$, rinsed with buffer and then incubated for $30 \mathrm{~min}$ (or $10 \mathrm{~min}$, as marked) with buffer containing a $1 \mathrm{mM}$ level of the $1{ }^{14} \mathrm{C}$-labeled amino acid whose transport was to be measured. The specified, nonradioactive amino acid was added to the final incubation medium. 4-15 samples per group.

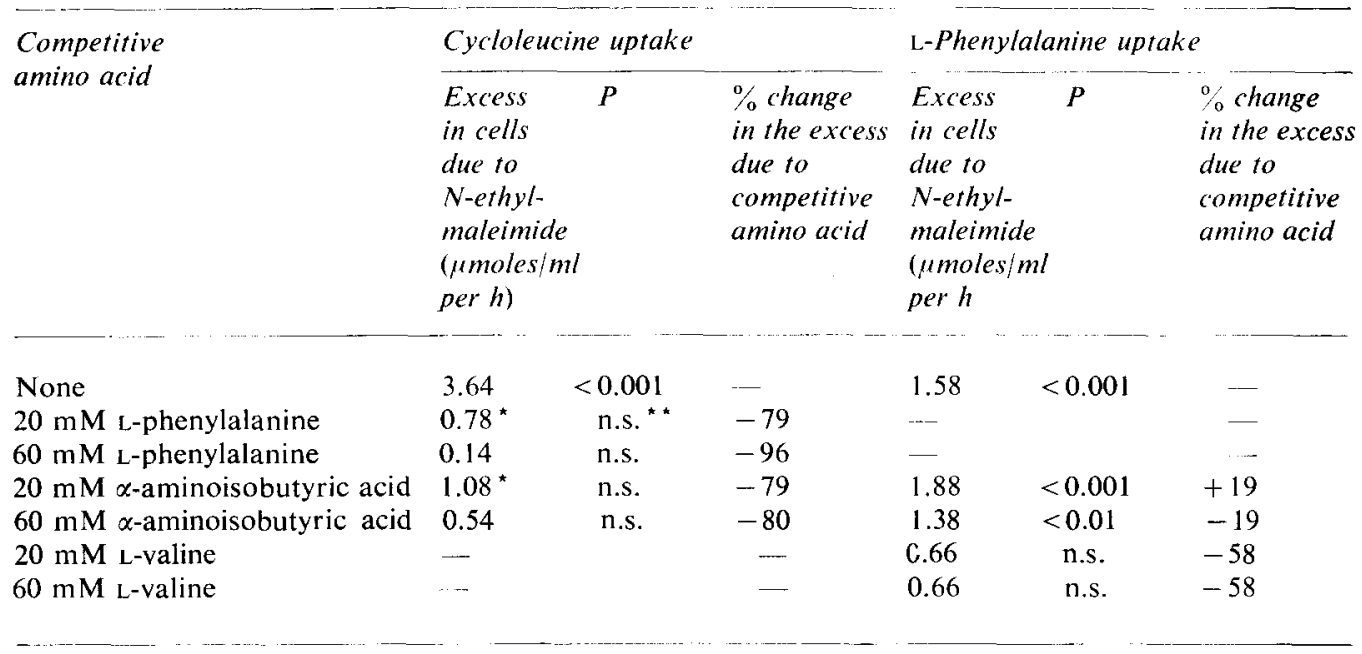

* Final incubation period $10 \mathrm{~min}$ instead of $30 \mathrm{~min}$.

* * Change due to $N$-ethylmaleimide was not significant.

\section{DISCUSSION}

The most striking feature of the $N$-ethylmaleimide action on cycloleucine uptake by the uterus is the gradation from stimulation to inhibition as the level and/or length of exposure to the agent is increased. A low level or a short exposure to $N$-ethylmaleimide led to stimulation; while a higher level along with, or in place of, a longer exposure caused the stimulation to fall off, and eventually produced inhibition, as seen in Fig. 3. The $\mathrm{N}$-ethylmaleimide is most probably binding to the uterus in producing its effects, as is shown by two facts: a brief exposure during a preincubation ( 10 min or less) was sufficient to produce the effects; and, the effects of $N$-ethylmaleimide were not diminished if thiols were added after the $N$-ethylmaleimide. The evidence suggests that there are at least two kinds of transport-related groups in the uterus that react with $\mathrm{SH}$ agents: one combines relatively rapidly with the agent to stimulate the 
uterine amino acid uptake, and the other combines more slowly to inhibit it. The stimulation of cycloleucine uptake declines when the inhibitory action becomes greater than the stimulatory one. The presence of fast- and slow-reacting SH groups in membranes has been demonstrated by van Steveninck et al. ${ }^{12}$, in the erythrocyte.

The apparent presence of two distinct effects of $N$-ethylmaleimide on amino acid transport suggests that the $\mathrm{SH}$ agent is acting on two separate amino acid transport systems in the uterus. Our earlier studies ${ }^{3}$ have suggested that this tissue contains transport systems comparable to the $\mathrm{A}$ and $\mathrm{L}$ systems described by Oxender, Christensen and associates in Ehrlich ascites tumor cells and other tissues ${ }^{13}$. Most of the data given here are consistent with the hypothesis that $N$-ethylmaleimide acts on the $\mathrm{L}$ system of the uterus to increase transport, while it acts on the A system to inhibit it. Several lines of evidence support this conclusion.

(1) Cycloleucine was the only amino acid tested whose uptake could be both stimulated and inhibited by $N$-ethylmaleimide. This is the expected result in view of the evidence that cycloleucine generally can be transported fairly well by both $\mathrm{A}$ and $\mathrm{L}$ systems. Of the other amino acids tested, phenylalanine and valine are classical L system amino acids, and are stimulated but not inhibited by $N$-ethylmaleimide. In contact, $\alpha$-aminoisobutyric acid, an A system amino acid, is only inhibited by $\mathrm{N}$ ethylmaleimide.

(2) For cycloleucine uptake, neither estradiol nor a lowlevel of $N$-ethylmaleimide altered the stimulatory effect given by the other one alone; but higher levels of $N$-ethylmaleimide inhibited the estradiol stimulation more than it affected cycloleucine uptake in unprimed uteri. Good evidence has been presented earlier that estradiol acts only on the A system in the uterus ${ }^{3}$. Except for cycloleucine, estradiol does not stimulate transport of those amino acids that are stimulated by $N$-ethylmaleimide (valine, phenylalanine); and, conversely, $N$-ethylmaleimide inhibited uptake of $\alpha$-aminoisobutyric acid, which is stimutaled strongly by estradiol. The stimulatory action appears, therefore, to be on a system not affected by estradiol, e.g. the $\mathrm{L}$ system. The inhibiton, in contrast, involves the same system affected by estradiol, namely, system A.

(3) The competitive-inhibition data of Table VIII generally support the conclusion that $\mathrm{N}$-ethylmaleimide acts on two transport systems in the uterus. The $\mathrm{N}$ ethylmaleimide stimulation of phenylalanine uptake was inhibited by valine but not by $x$-aminoisobutyric acid. If $N$-ethylmaleimide increased transport by an action on the $L$ system, valine would be expected to decrease the effect on phenylalanine uptake, since they are both $L$ system amino acids. In contrast, $\alpha$-aminoisobutyric acid would not be expected to alter the stimulation, since it uses the A system. When cycloleucine uptake was measured, however, both phenylalanine and $\alpha$-aminoisobutyric acid greatly depressed the increment in uptake produced by $N$-ethylmaleimide. The effect of phenylalanine would be expected; but the decrease due to $\alpha$-aminoisobutyric acid suggests that the inhibition of cycloleucine uptake by the A system had some influence on its transport by the $L$ system as well. The absence of an effect of $\alpha$-aminoisobutyric acid on the $N$-ethylmaleimide stimulation of phenylalanine uptake supports the idea that cycloleucine transport is unique.

(4) A low level of $N$-ethylmaleimide gave a similar increment of increase in cycloleucine uptake in the preincubated uterus as in the normal tissue. With an inhibitory condition, however, the increment due to $\mathrm{N}$-ethylmaleimide was decreased 
more than normal in the preincubated sample (Table VII). We have already concluded that preincubating the uterus leads to an increase in transport by the $A$ system ${ }^{11}$. Hence, the greater sensitivity of the preincubated uterus to inhibition by $N$-ethylmaleimide, and its essentially unaltered sensitivity to stimulation (both in absolute terms), again supports the idea that the A system is the one subject to $N$-ethylmaleimide inhibition.

Results from the experiments with $\mathrm{Na}^{+}$-free media would at first appear to be inconsistent with the above conclusion. Transport of amino acids by the L system does not normally require $\mathrm{Na}^{+}$(ref. 14), but maximum stimulation by $N$-ethylmaleimide does (Table VI). In addition, the $N$-ethylmaleimide stimulation can be inhibited by ouabain. The fact that $\mathrm{Na}^{+}$is required for $N$-ethylmaleimide stimulation does not necessarily mean, however, that the $\mathrm{SH}$ agent is modifying a $\mathrm{Na}^{+}$-sensitive transport system. Rather, the cation might act at a point quite independent of the transport step. This latter conclusion seems likely in view of the other evidence that the stimulation involves the L system.

Finally, some additional comments are necessary regarding the effects of $\mathrm{N}$ ethylmaleimide and estradiol together. The two agents clearly act in different ways to stimulate amino acid transport, since they affect different transport systems. The inhibition by $\mathrm{N}$-ethylmaleimide, however, apparently involves the estradiol-sensitive system. This inhibition nevertheless does not appear to be due to an interference of the binding of estradiol with uterine sites. This conclusion is suggested primarily by the fact that $N$-ethylmaleimide, added in vitro, can inhibit the estradiol effect in very short times, even though the hormone has already acted for $3 \mathrm{~h}$ or more. The results suggest that $N$-ethylmaleimide affects some late step in the process by which estradiol stimulates amino acid transport.

\section{ACKNOWLEDGMENT}

This work was supported in part by grant AM-03709, National Institutes of Health, United States Public Health Service.

\section{REFERENCES}

I Feng, H. W., Pan, M. W. and Riggs, T. R. (1967) Fed. Proc. 26, 535

2 Roskoski, Jr, R. and Steiner, D. F. (1967) Biochim. Biophys. Acta 135, 727-731

3 Riggs, T. R., Pan, M. W. and Feng, H. W. (1968) Biochim. Biophys. Acta 150, 92-103

4 Sutherland, R., Rothstein, A. and Weed, R. I. (1967) J. Cell. Physiol. 69, 185-198

5 Brierley, G. P., Jacobus, W. E. and Hunter, G. R. (1967) J. Biol. Chem. 242, 2192-2198

6 Stein, W. D. (1967) The Movements of Molecules Across Cell Membranes, pp. 289-295, Academic Press, New York

7 Jensen, E. V., Hurst, D. J., DeSombre, E. R. and Jungblut, P. W. (1967) Science 158, 385-387

8 Ukolova, M. A. and Kvakina, E. B. (1966) Fed. Proc. 25, T1019--T1022

9 Batt, E. R. and Schachter, D. (1971) Biochim. Biophys. Acta 233, 189-200

10 Benesch, R., Benesch, R. V., Gutcho, M. and Laufer, L. (1956) Science 123, 981-982

11 Riggs, T. R. and Pan, M. W. (1972) Biochem. J. 128, 19-27

12 van Steveninck, J., Weed, R. I. and Rothstein, A. (1965) J. Gen. Physiol. 48, 617-632

13 Christensen, H. N. (1967) Perspect. Biol. Med. 10, 471-494

14 Riggs, T. R., Pan, M. W. and Feng, H. W. (1972) J. Biol. Chem. 247, 7128-7134 